\title{
ANALISIS MOTIVASI KERJA TERHADAP PRODUKTIVITAS KERJA KARYAWAN PT.CIOMAS ADISATWA BANDAR LAMPUNG
}

\author{
Pairi $^{(1)}$, Kuswarak $^{(2)}$, Iwan Zulfikar ${ }^{(3)}$ \\ Fakultas Ekonomi Universitas Sang Bumi Ruwa Jurai \\ pairi013@gmail.com,kuswarak@fe.saburai.ac.id,iwan.zulfikar@fe.saburai.ac.id
}

\begin{abstract}
Abstrak. Karyawan di PT.Ciomas Adisatwa Bandar Lampung menghadapi beberapa masalah seperti masih rendahnya motivasi yang diberikan oleh perusahaan dan kurangnya dukungan akan karyawan yang memiliki prestasi baik, sehingga produktivitas kerja karyawan di lingkungan PT.Ciomas Adisatwa Bandar Lampung cenderung menurun. Tujuan dilakukannya penelitian ini adalah untuk mengetahui ada atau tidaknya pengaruh motivasi kerja terhadap produktivitas kerja karyawan PT.Ciomas Adisatwa Bandar Lampung. Hipotesis penelitian yang diajukan adalah "Motivasi kerja berpengaruh positif dan signifikan terhadap produktivitas kerja karyawan PT.Ciomas Adisatwa Bandar Lampung". Pengumpulan data penelitian ini menggunakan teknik populasi dari seluruh karyawan PT.Ciomas Adisatwa Bandar Lampung yang berjumlah 30 orang. Analisis yang digunakan dalam penelitian ini adalah analisis regresi linear sederhana. Berdasarkan hasil analisis pengaruh motivasi kerja terhadap produktivitas kerja karyawan ditunjukkan pada angka koefisien regresi sebesar 0,943 dengan nilai signifikan yang lebih kecil dari 0,05, terlihat bahwa motivasi kerja berpengaruh signifikan terhadap produktivitas kerja pegawai pada taraf kepercayaan 95\%. Dengan demikian, semakin baik tingkat motivasi kerja karyawan, maka akan semakin tinggi pula produktivitas kerja karyawan PT. Ciomas Adisatwa Bandar Lampung.
\end{abstract}

Kata kunci: Karyawan, Kerja, Motivasi, Produktivitas.

\section{PENDAHULUAN}

Produktivitas merupakan salah satu komponen yang harus dimiliki oleh suatu perusahaan apabila ingin mencapai tujuan yang telah ditetapkan perusahaan. Suatu perusahaan atau organisasi tidak dapat mencapai tujuannya secara efisien dan efektif apabila produktivitas kerja karyawan rendah. Oleh sebab itu produktivitas menjadi penting yang selalu ingin ditingkatkan karena dapat menggambarkan tingkat efesiensi kerja karyawan. Dalam melaksanakan target produktivitas, sumber daya manusia memegang peran penting, karena kegiatan perusahaan tidak mungkin dapat dilakukan dengan baik tanpa didukung oleh sumber daya manusia. Maka diperlukan suatu rangsangan untuk meningkatkan produktivitas kerja, agar memperoleh hasil untuk mencapai tujuan perusahaan.
Pegawai (karyawan) memiliki perilaku, sikap, motivasi dan kebiasaan yang tumbuh dan berkembang yang dibentuk oleh kondisi lingkungan serta pengalamanpengalaman di tempat kerja. Untuk dapat mendorong pegawai ke arah usaha maksimal dibutuhkan kebijakan pimpinan dalam usaha menggerakkan, mengajak dan mengarahkan bawahannya. Kebijakan harus mampu memberikan dorongan atau motivasi untuk mencapai produktivitas kerja yang baik.

Untuk memotivasi pegawai bukanlah hal yang mudah, karena manusia mempunyai perilaku yang berbeda antara satu dengan yang lainnya dalam memenuhi kebutuhan dan harapan-harapannya. Oleh karena itu menjadi kewajiban dari setiap pemimpin untuk mendorong dan memotivasi setiap bawahannya untuk berprestasi. Prestasi pegawai terutama ditentukan oleh kemampuan dan daya 
dorong. Kemampuan seorang individu dibentuk oleh kualifikasi yang dimilikinya seperti pendidikan, pengalaman dan karakteristik-karakteristik pribadi, sedangkan daya dorong dipengaruhi oleh faktor-faktor internal, yaitu lingkungan sekitarnya (Samir, 1993).

Untuk dapat mengikuti segala perkembangan yang ada dan tercapainya tujuan organisasi, maka PT.Ciomas Adisatwa perlu adanya suatu motivasi agar pegawai mampu bekerja dengan baik, dan salah satu motivasi itu adalah dengan memenuhi keinginan-keinginan pegawai antara lain: gaji atauupah yang baik, pekerjaan yang aman, suasana kerja yang kondusif, penghargaan terhadap pekerjaan yang dilakukan, pimpinan yang adil dan bijaksana, pengarahan dan perintah yang wajar, organisasi atau tempat kerja yang dihargai masyarakat atau dengan mengupayakan insentif yang besarannya proporsional dan jugabersifat progresif yang artinya sesuai dengan jenjang karir, karena insentif sangat diperlukan untuk memacu kinerja para pegawai agar selalu berada pada tingkat tertinggi (optimal) sesuai kemampuan masing-masing. Faktorfaktor yang dapat digunakan untuk meningkatkan produktivitas kerja pegawai diantaranya motivasi yang diberikan (Robbins, 2003).

Permasalahan dalam pengelolaan manajemen sumber daya manusia dapat terjadi di bidang organisasi usaha apa saja, baik itu pada perusahaan yang bergerak di bidang industri maupun jasa. PT.Ciomas Adisatwa merupakan perusahaan yang bergerak di bidang kemitraan ayam potong (broiler). Dalam kegiatan usahanya PT.Ciomas Adisatwa harus mampu bersaing/berkompetisi agar lebih cepat berkembang dan lebih maju.

Namun dalam pelaksanaannya, berdasarkan hasil observasi di PT.Ciomas Adisatwa Bandar Lampung bahwa fenomena yang terjadi adalah masih rendahnya motivasi yang diberikan oleh perusahaan seperti kurangnya dukungan akan pegawai yang memiliki prestasi yang baik, sehingga produktivitas kerja karyawan di lingkungan PT.Ciomas Adisatwa sangatlah menurun.

Berdasarkan survey yang telah lakukan, terlihat bahwa produktivitas kerja karyawan PT.Ciomas Adisatwa masih harus ditingkatkan lagi, hal ini dapat dilihat dari kegiatan karyawan sehari-hari dalam melakukan tugas dan pekerjaanya, masih ada karyawan yang datang terlambat dari jam masuk yang telah ditentukan, istirahat yang terlalu lama, pulang terlalu awal dan sebagainya. Dalam hal ini peneliti tertarik meneliti permasalahan yang dihadapi PT. Ciomas Adisatwa Bandar Lampung dengan judul: "Analisis Motivasi Kerja terhadap Produktivitas Kerja Karyawan PT.Ciomas Adisatwa Bandar Lampung".

\section{KAJIAN TEORI}

\section{Pengertian Motivasi}

Motivasi berasal dari kata latin "movere" yang berarti dorongan atau menggerakkan. Motivasi adalah hal yang menyebabkan, menyalurkan, dan mendukung prilaku manusia supaya mau bekerja giat dan antusias mencapai hasil yang optimal. Motivasi semakin penting karena manajer membagikan pekerjaan pada bawahannya untuk dikerjakan dengan baik dan integritas kepada tujuan yang diinginkan (Hasibuan, 2007). Untuk mempermudah pemahaman motivasi kerja, berikut ini dikemukakan beberapa pengertian motivasi dari beberapa ahli manajemen.

Menurut Veithzal Rivai (2006) motivasi adalah serangkaian sikap dan nilai-nilai yang mempengaruhi individu untuk mencapai hal yang spesifik sesuai dengan tujuan individu. Sedangkan menurut Edwin B Flippo dalam Malayu S.P 
Hasibuan (2007) motivasi adalah suatu keahlian dalam mengarahkan pegawai dan organisasi agar mau bekerja secara berhasil, sehingga keinginan para pegawai dan tujuan organisasi sekaligus tercapai. Serta menurut G.R. Terry dalam Malayu S.P Hasibuan (2007) motivasi adalah keinginan yang terdapat pada diri seseorang individu yang merangsangnya untuk melakukan tindakan-tindakan.

Dari beberapa pendapat diatas, maka motivasi adalah keseluruhan daya penggerak didalam diri dengan ditanadai timbulnya perasaan dan reaksi yang menimbulkan kegiatan belajar menjamin kelangsungan dan memberikan arah pada kegiatan belajar sehingga tujuan yang dikehendaki dapat tercapai.

\section{Tujuan Motivasi}

Menurut Malayu S.P Hasibuan (2007) tujuan motivasi adalah sebagai berikut :

1) Meningkatkan moral dan kepuasan kerja karyawan.

2) Meningkatkan produktivitas kerja karyawan.

3) Mempertahankan kestabilan karyawan perusahaan.

4) Meningkatkan kedisiplinan karyawan.

5) Mengefektifkan pengadaan karyawan.

6) Menciptakan suasana dan hubungan kerja yang baik.

7) Meningkatkan loyalitas, kreativitas, dan partisipasi karyawan.

8) Meningkatkan tingkat kesejahteraan karyawan.

9) Mempertinggi rasa tanggung jawab karyawan terhadap tugas-tugasnya.

10) Meningkatkan efisiensi penggunaan alat-alat dan bahan baku.

\section{Motivasi Sebagai Penentu Produktivitas Kerja}

Banyak penelitian yang telah dilakukan tentang motivasi kerja dalam prestasi yang telah mendorong lahirnya berbagai teori motivasi. Namun sayang antara teori yang satu dengan yang lain tidak terdapat keserasian karena masing-masing hanya memperhatikan segi-segi tertentu saja dari motivasi.

Seluruh teori-teori itu pada hakikatnya dapat dikelompokan ke dalam dua kelompok teori, yaitu teori-teori menyangkut proses dan teori-teori yang menyangkut kepuasan atau kebutuhan. Teori tentang proses menentukan perilaku manusia yang dapat digiatkan dan dipertahankan. Sedangkan teori kepuasan adalah mengenai adanya apa yang terdapat dalam diri seseorang atau lingkungan orang-orang itu yang menggiatkan dan mempertahankan perilaku orang tersebut.

Setiap pegawai atau karyawan yang memasuki lingkungan kerja memiliki tujuan tertentu dan tujuan inilah yang mendorong atau memotivasi dirinya untuk terlibat dalam suatu lingkungan kerja. Hal ini searah dengan pandangan Kohar (1994) yang mengatakan bahwa tujuan orang bekerja adalah untuk memenuhi kebutuhan hidupnya, terlepas dari apa dan bagaimana jenis dan kebutuhan yang ingin dipenuhi.

Menurut Susilo (1996) motivasi merupakan bagian integral dari manajemen dalam rangka melaksanakan tugas yang menjadi tanggung jawabnya sesuai ketentuan, aturan dan kebijakan organisasi. Selanjutnya Samir Sofian (1993) mengatakan bahwa motivasi adalah suatu kemampuan untuk mempunyai rasa keterlibatan atau keterikatan moral dan tanggung jawab dalam organisasi untuk melaksanakan tugas dan kewajibannya dengan sungguh-sungguh guna mewujudkan tujuan organisasi secara efisien dan efektif.

Dalam pandangan yang lebih luas Masri (1987) berpendapat bahwa motivasi kerja merupakan fungsi yang melekat baik pada pimpinan maupun bagi pelaksanaan operasional organisasi yang saling 
mempengaruhi dalam proses pelaksanaan kegiatan-kegiatan yang dilakukan akan ditentukan oleh ada tidaknya motivasi kerja atau mewujudkannya.

\section{Faktor-Faktor Yang Mempengaruhi Produktivitas Kerja}

Setiap perusahaan selalu berkeinginan agar tenaga kerja yang dimiliki mampu meningkatkan produktivitas yang tinggi. Produktivitas tenaga kerja dipengaruhi oleh beberapa faktor baik yang berhubungan dengan tenaga kerja itu sendiri maupun faktor lain. Menurut Simanjuntak dalam Edy Sutrisno (2009), yaitu antara lain :

1. Pelatihan

Latihan kerja dimaksudkan untuk melengkapi karyawan dengan keterampilan dan carta-cara yang tepat untuk menggunakan peratan kerja. Untuk itu, latihan kerja diperlukan bukan saja sebagai pelengkap akan tetapi sekaligus untuk memberikan dasar-dasar pengetahuan.

2. Mental dan Kemampuan Fisik Karyawan

Keadaan mental dan fisik karyawan merupakan hal yang sangat penting untuk menjadi perhatian bagi organisasi, sebab keadaan fisik dan mental karyawan mempunyai hubungan yang sangat erat dengan produktivitas kerja karyawan.

3. Hubungan antara atasan dan bawahan

Hubungan atasan dan bawahan akan mempengaruhi kegiatan yang dilakukan sehari-hari.

\section{METODE PENELITIAN}

\section{Objek Penelitian}

Objek penelitian ini adalah Karyawan di PT.Ciomas Adisatwa Bandar Lampung, yang beralamat di Jalan Pattimura, Kec. Teluk Betung, Bandar Lampung. Penelitian ini dilaksanakan dari bulan Januari sampai dengan April 2017.

\section{Metode dan Teknik Pengumpulan Data}

Dalam penelitian ini jenis data yang diperlakukan adalah :

a. Data Primer

Data primer merupakan data dasar yang akan diperoleh langsung tanpa perantara orang atau lembaga lain sebagai pihak ketiga. Data primer ini diperoleh dengan wawancara melalui responden dengan menggunakan daftar pertanyaan.

\section{b. Data Sekunder}

Data skunder merupakan data yang diperoleh melalui orang lain yang berhubungan dengan permasalahan yang dipecahkan. Data sekunder ini diperoleh melalui cara studi dokumenter yaitu mengumpulkan dan mempelajari brosurbrosur serta dokumen organisasi.

Langkah-langkah pengumpulan data yang penulis lakukan dengan mengadakan penelitian lapangan yaitu Penelitian yang dilakukan di PT.Ciomas Adisatwa Bandar Lampung, adapun teknik yang digunakan dalam pengumpulan data adalah dengan :

1. Observasi, yaitu mengadakan survey atau pengamatan langsung kelokasi penelitian.

2. Interview atau wawancara, yaitu mengadakan tanya jawab langsung dengan karyawan pada PT.Ciomas Adisatwa Bandar Lampung.

3. Dokumentasi, yaitu mengumpulkan dan mencatat dokumentasi yang relevan.

4. Kuisioner, yaitu membuat pertanyaan yang berhubungan dengan varibael penelitian.

\section{Sampel dan Populasi}

Andi Supangat (2007) mengemukakan, sampel adalah "bagian dari populasi 
(contoh) untuk dijadikan sebagai bahan penelaahan dengan harapan contoh yang diambil dari populasi tersebut dapat mewakili (representative) terhadap populasinya" oleh karena itu sampel yang digunakan pada penelitian ini adalah sampel total atau sampling jenuh seperti yang diungkapkan oleh Sugiyono (2010) bahwa "sampling jenuh adalah teknik penentuan sampel bila semua anggota populasi digunakan sebagai sampel". Jadi, responden dalam penelitian ini berjumlah 30 orang.

\section{Metode Analisis Data}

Analisis kuantitatif yang dilakukan berdasarkan data primer yang diperoleh dari penyebaran instrument (daftar pertanyaan) kepada sampel, dan untuk mengetahui pengaruh dari variabel bebas (independent variable) terhadap variabel terikat (dependent variable).

Persamaan Regresi Linear Sederhana menentukan persamaan regresi linear sederhana untuk X :

$$
Y=a+b X+e
$$

Keterangan:

$$
\begin{aligned}
& \mathrm{Y}=\text { Produktivitas kerja } \\
& \mathrm{a}=\text { Konstanta } \\
& \mathrm{b}=\text { Koefisien regresi } \mathrm{X} \\
& \mathrm{X}=\text { Motivasi kerja } \\
& \mathrm{e}=\text { Faktor kesalahan }
\end{aligned}
$$

Untuk mengetahui besarnya pengaruh, penghitungan koefisien korelasi tersebut kemudian dilanjutkan dengan Rumus Koefisien Determinasi atau Koefisien Penentu (KP):

$$
K P=(r)^{2} x 100 \%
$$

Untuk menguji secara hipotesis secara parsial digunakan Uji t dengan rumus :

$$
t_{\text {hitung }}=\frac{r \sqrt{N-2}}{\sqrt{1-r^{2}}}
$$

Keterangan:

$$
\begin{array}{ll}
\mathrm{t}_{\text {hitung }} & =\text { Nilai } \mathrm{t} \\
\mathrm{r} & =\text { Koefisien Korelasi } \\
\mathrm{N} & =\text { Jumlah responden }
\end{array}
$$

Kriteria untuk Uji $\mathrm{t}$ adalah sebagai berikut :

a) Jika $t_{\text {hitung }}>t_{\text {tabel }}$ maka Ha diterima dan Ho ditolak.

b) Jika $t_{\text {hitung }} \leq \mathrm{t}$ tabel maka Ha ditolak dan Ho diterima.

\section{HASIL DAN PEMBAHASAN}

\section{Uji Validitas}

Uji validitas ini dilakukan dengan tujuan untuk mengetahui kesahihan dari angket atau kuisioner. Kesahihan di sini mempunyai arti kuesioner atau angket yang digunakan mampu untuk mengukur apa yang seharusnya diukur. Suatu kuisioner dikatakan valid (handal) jika jawaban seorang terhadap pertanyaan yang terdapat dalam kuisioner tersebut adalah konsisten atau stabil dari waktu ke waktu.

Uji validitas ini dilakukan dengan menggunakan metode koefisien korelasi 45 dengan rumus korelasi Product Moment Pearson. Instrumen dapat dikatakan valid apabila mempunyai $r_{\text {hitung }}$ yang diperoleh $\geq$ 0,300 pada tingkat kepercayaan $95 \%$. Hasil perhitungan validitas instrumen disajikan pada Tabel 1 .

Tabel 1. menunjukkan bahwa semua item indikator yang mengukur masingmasing variabel indikator menghasilkan angka koefisien validitas yang lebih dari $0,300$ ( $\mathrm{r}>0,30)$. Dengan demikian, dapat dinyatakan bahwa instrumen pengumpulan data yang digunakan dalam penelitian ini adalah valid. 
Tabel 1. Hasil Uji Validitas Instrumen pada Taraf $\alpha$

\begin{tabular}{|c|c|c|c|}
\hline Variahel & & & \\
\hline & & Korelasi & \\
\hline Motivasi & $\mathrm{X}_{1}$ & 0,707 & Valid \\
\hline \multirow[t]{5}{*}{ Kerja (X) } & $\mathrm{X}_{2}$ & 0,907 & Valid \\
\hline & $X_{3}$ & 0,582 & Valid \\
\hline & $\mathrm{X}_{4}$ & 0,480 & Valid \\
\hline & $\mathrm{X}_{5}$ & 0,606 & Valid \\
\hline & $\mathrm{X}_{6}$ & 0,907 & Valid \\
\hline Produktivitas & $\mathrm{Y}_{1}$ & 0,778 & Valid \\
\hline \multirow[t]{5}{*}{ Kerja (Y) } & $\mathrm{Y}_{2}$ & 0,833 & Valid \\
\hline & $\mathrm{Y}_{3}$ & 0,643 & Valid \\
\hline & $\mathrm{Y}_{4}$ & 0,829 & Valid \\
\hline & $\mathrm{Y}_{5}$ & 0,855 & Valid \\
\hline & $\mathrm{Y}_{6}$ & 0,688 & Valid \\
\hline
\end{tabular}

\section{Uji Reliabilitas}

Uji reliabilitas merupakan uji kehandalan yang bertujuan untuk mengetahui seberapa jauh sebuah alat ukur dapat diandalkan atau dipercaya. Pengujian reliabilitas terhadap seluruh item/pertanyaan yang dipergunakan dalam penelitian ini akan menggunakan formulasi cronbach alpha (koeisien alpha cronbach), di mana secara umum yang dianggap realibel apabila nilai alpha cronbachnya > 0,600 . Pengujian reliabilitas instrumen pada taraf kepercayaan $95 \%(\alpha=0,05)$ disajikan pada Tabel 2.
Tabel 2. Hasil Uji Reliabilitas Instrumen pada Taraf $\begin{array}{cc}\alpha=0,05 & \\ \text { Variabel Cronbach's Keterangan }\end{array}$ Alpha

\begin{tabular}{lll} 
Motivasi & 0,801 & Reliabel \\
Kerja (X) & & \\
Produktivitas & & \\
Kerja (Y) & 0,864 & Reliabel \\
& & \\
\hline
\end{tabular}

Tabel 2. menunjukkan bahwa semua item indikator yang digunakan untuk mengukur masing-masing variabel memiliki angka koefisien yang lebih besar dari 0,600. Oleh karena itu, instrumen yang digunakan dalam mengumpulkan data dinyatakan reliabel pada taraf kepercayaan $95 \%$.

\section{Analisis Kuantitatif}

Pengujian hipotesis adalah uji yang dilakukan untuk membuktikan hipotesis penelitian. Hipotesis dalam penelitian ini berkaitan dengan terdapat tidaknya pengaruh signifikan variabel independen terhadap variabel dependen. Hasil analisis regresi linear sederhana dapat diinterpretasikan sebagai signifikansi pengaruh variabel motivasi kerja (X) terhadap produktivitas kerja pegawai (Y), diperoleh nilai $\left.\mathrm{F}_{\text {tabel }}\left(\mathrm{F}_{(0,05,1,28)}\right)=4,196\right)$, dengan nilai signifikansi sebesar $F_{h i t u n g}=$ 224,568 yang berarti $F_{\text {hitung }}$ lebih dari $F_{\text {tabel }}$. Hasil ini berarti Ho ditolak dan menerima Ha. menunjukkan bahwa motivasi kerja (X) berpengaruh signifikan terhadap produktivitas kerja pegawai (Y).

Hasil analisis statistik menggunakan analisis regresi linear sederhana yang dilakukan untuk melihat besarnya pengaruh motivasi kerja terhadap produktivitas kerja 
karyawan di PT.Ciomas Adisatwa Bandar, maka diperoleh persamaan regresi linier sederhana $\mathrm{Y}=2,569+0,904 \mathrm{X}+\mathrm{e}$.

Angka konstanta $(\beta 0)$ sebesar 2,569 dengan nilai signifikan sebesar 0,104 yang berarti lebih besar dari nilai $\alpha=0,05$, maka dapat diinterpretasikan bahwa secara statistika, nilai konstanta $(\beta 0)$ tersebut tidak berbeda nyata dengan nol. Karena itu, nilai konstanta tersebut tidak dapat dimasukkan dalam model regresi. Nilai R2 (R-Square) sebesar 0,889 menunjukkan bahwa besarnya pengaruh langsung motivasi kerja terhadap produktivitas kerja adalah $88,9 \%$, sehingga pengaruh variabel lain yang tidak dijelaskan dalam model sebesar 11,1\%. Nilai R (angka koefisien korelasi) sebesar 0,943 menunjukkan bahwa keeratan hubungan langsung antara motivasi kerja terhadap produktivitas kerja adalah sebesar $94,3 \%$.

Hubungan ini secara statistik tergolong sangat kuat. Hal ini sebagaimana yang dikemukakan oleh Syahri Alhusin (2002) bahwa hubungan yang tergolong sangat kuat adalah 0,80 - 1,00. Oleh karena itu, model regresi yang dihasilkan dapat dikatakan sebagai model yang "fit" atau dapat menjadi model penduga yang baik dalam menjelaskan pengaruh motivasi kerja terhadap produktivitas kerja pegawai PT.Ciomas Adisatwa Bandar Lampung.

\section{KESIMPULAN DAN SARAN}

\section{Kesimpulan}

Berdasarkan hasil analisis dan pengujian hipotesis yang telah dilakukan, maka kesimpulan dalam adalah motivasi kerja berpengaruh positif dan signifikan terhadap produktivitas kerja. Arah dan signifikan pengaruh motivasi kerja terhadap produktivitas kerja pegawai, ditunjukkan pada angka koefisien regresi sebesar 0,934 dengan nilai signifikan yang lebih kecil dari 0,05. Angka ini menyatakan bahwa motivasi kerja berpengaruh signifikan terhadap produktivitas kerja pegawai pada taraf kepercayaan 95\%. Dengan demikian dapat diinterpretasikan bahwa semakin baik tingkat motivasi kerja pegawai (bawahan), maka akan semakin tinggi pula produktivitas kerja pegawai PT.Ciomas Adisatwa Bandar Lampung.

\section{Saran}

Adapun saran yang diajukan peneliti adalah sebagai berikut :

1. Untuk penelitian selanjutnya, disarankan untuk menambah variabel bebas yang lain seperti pengetahuan, budaya organisasi, guna melihat lebih lanjut faktor-faktor yang mempengaruhi kinerja pegawai.

2. Dalam meningkatkan produktivitas kerja pegawai maka faktor penting yang harus diperhatikan oleh pimpinan, khususnya di PT. Ciomas Adisatwa Bandar Lampung, yakni motivasi kerja pegawai, sehingga produktivitas kerja pegawai dapat dipertahankan dan ditingkatkan lebih baik lagi.

\section{DAFTAR PUSTAKA}

Arikunto, S. 2002. Prosedur Penelitian Suatu Pendekatan, Praktek, Edisi Revisi V, Cetakan Kedua Belas, Jakarta: Rineka Cipta.

Hasibuan, S.P. Malayu. 2007. Organisasi dan Motivasi. Jakarta: PT. Bumi Aksara.

Kohar, Kamaruddin. 1994. Manajemen Tenaga Kerja. Jakarta: Akara Baru.

Mangkunegara, Anwar Prabu. 2007. Manajemen Sumber Daya Manusia Perusahaan. Bandung: Penerbit Rosdakarya. 
Masri, Maris. 1987. Manajemen Sumber Daya Manusia. Jakarta: Media Asri.

Moekijat. 1984. Dasar-Dasar Motivasi, Bandung : Sumur Bandung Masri.

Payman J. Simananjuntak. 1985. Pengantar Ekonomi Sumber Daya Manusia. Jakarta: Lembaga Penerbit Fakultas Ekonomi Universitas Pendidikan Indonesia.

Ranupandojo, H. 1999. Manajemen Personalia. Edisi III. Yogyakarta: BPFE.

Ravianto, J. 2001. Produktivitas dan Manajemen. Jakarta: Bumi Aksara.

Rivai, Veitzal. 2006. Manajemen Sumber Daya Manusia untuk Perusahaan: Dari Teori ke Praktik. Jakarta: PT.Raja Grafindo Persada.

Robbins, Stephen. P., 2003. Perilaku Organisasi. Jilid 1 (Edisi Terjemahan). Jakarta: PT.Gramedia.

Samir, Sofyan. 1993. Motivasi Pegawai dan Pendekatan Manusiawi. Jakarta: Rineka Cipta.

Sarwoto, Susilo. 1996. Membangun Motivasi Kerja. Jakarta: Media Asri.

Siagian, Sondang. P. 2001. Filsafat Administrasi. Jakarta: PT.Haji Masagung.

Sinungan, Muchdarsyah. 2005. Produktivitas : Apa dan Bagaimana. Edisi Kedua. Jakarta: Bumi Aksara.

Sugiyono. 2008. Metode Penelitian Kunatitatif Kualitatif dan $R \& D$. Bandung: Alfabeta.
Wahjosumidjo. 2002. Kepemimpinan dan Motivasi. Jakarta: Ghalia Indonesia.

Westerman, Jhon. 1992. Pengelolaan Sumber Daya Manusia. Jakarta: Bumi Aksara.

Winardi, J. 2000. Motivasi dan Pemotivasian dalam Manajemen. Jakarta: PT.Raja Grafindo Persada.

Wursanto, I.G. 1992. Manajemen Kepegawaian 1. Yogyakarta: Kansius. 